American Journal of Environmental Sciences 4 (4): 388-396, 2008

ISSN 1553-345X

(C) 2008 Science Publications

\title{
Desalination of Saline Sludges Using Ion-Exchange Column with Zeolite
}

\author{
A.E. Ghaly and M. Verma \\ Department of Process Engineering and Applied Sciences, Dalhousie University, \\ Halifax, Nova Scotia, B3J 2X4, Canada
}

\begin{abstract}
A flushing process followed by a zeolite based ion-exchange process were developed for the treatment of saline sludges from oil and gas exploration sites. The particle size distribution of sludge sample indicated the presence of very fine sand and clay. The electrical conductivity of the sludge was $42.2 \mathrm{dS} \mathrm{m}^{-1}$ indicating very saline sludge and the Cation Exchange Capacity (CEC) was $40 \mathrm{cmoL} \mathrm{kg}^{-1}$ which was very suitable for ion-exchange process. A $500 \mathrm{~g}$ sample of saline sludge (containing $\mathrm{CaCl}_{2}: \mathrm{MgCl}_{2}: \mathrm{NaCl}$ ratio as 1:1.16:36.61) was washed using demineralized water in a mixed reactor and the sludge was allowed to settle for $36 \mathrm{~h}$. The optimal number of washes was determined to be two washes with an overall salt removal efficiency of $94.47 \%$. The treated sludge contained $515 \mathrm{mg}$ salt $\mathrm{kg}^{-1}$ sludge (or $0.05 \% \mathrm{w} \mathrm{w}^{-1}$ ) and was suitable for agricultural application. The washwater was passed through a Mountain Stronach zeolite (chabazite) based ion-exchange column for salt reduction. The sodium salt removal efficiency was $75.34 \%$. This was increased to $99.79 \%$ when using two ionexchange columns. The $\mathrm{Ca}$ and $\mathrm{Mg}$ ions were under regulatory limits and required no further treatment. The final salt concentration in the wash water was $314.0 \mathrm{mg} \mathrm{L}^{-1}$ which was below the limits established by the Canadian Guidelines. For complete removal of total salts, a series of ion-exchange columns with different zeolites (for removal of $\mathrm{NaCl}, \mathrm{MgCl}_{2}$ and $\mathrm{CaCl}_{2}$ ) will be required.
\end{abstract}

Key words: Saline sludge, salt, zeolite, washing, demineralization, desalination, EC, CEC, ion-exchange, $\mathrm{NaCl}, \mathrm{MgCl}_{2}, \mathrm{CaCl}_{2}$

\section{INTRODUCTION}

Soils may be salinized as a result of resource extraction and other human activities. However, most of soil salinity in western Canada is resulting from oil and gas exploration ${ }^{[1]}$. Saline water and sludge are usually produced during this process and stored on site. The current disposal of contaminated materials is inefficient and costly ${ }^{[2]}$. The remoteness of many sites complicates the disposal process as these sites are only accessible in winter ${ }^{[3]}$. Furthermore, the disposal process results in the storage of contaminated materials with no further treatment.

The result of not treating the contaminated material is the destruction of the vegetation and creation of bare $\operatorname{areas}^{[2,4,5]}$ as well as contamination of ground water ${ }^{[3,6]}$. The regulating bodies responsible for oil and gas operations in Canada are beginning to enforce clean ups to eliminate any potential environmental hazards ${ }^{[7]}$. Therefore, an economically sustainable efficient technology is required to remove salts from contaminated soils and sludges associated with oil and gas production.
The objective of this study was to develop a treatment process for a salt-contaminated sludge associated with natural gas and oil production. The specific objectives were: to develop an efficient salt removal process from saline sludge, to develop a water remediation system for the saline wash water and to evaluate the performance of the two processes.

\section{BACKGROUND}

Sludge remediation: Sludge is normally composed of largely water, biological compounds (microbial cells and various cellular products), organic solids, metals and several other pollutants which are usually above standard guidelines ${ }^{[8]}$. The complex physiology of sludge offers great challenges in separation of hazardous compounds ${ }^{[9]}$. Presently, there are different techniques used for the treatment of contaminated sludges including: conditioning, thickening/dewatering, composting and washing processes.

Conditioning of the sludge can be performed through chemical and thermal treatments. Chemical additives such as lime, ferric chloride and cyclodextrins

Corresponding Author: A.E. Ghaly, Professor, Department of Process Engineering and Applied Science, Dalhousie University, Halifax, Nova Scotia, Canada, B3J 2X4,Tel: 902-494-6014 
are used to act as chemical forces to drive together colloidal particles in the sludge ${ }^{[10-12]}$ whereas thermal conditioning involves heat and pressure as a method to drive particles together ${ }^{[8,13,14]}$.

Sludge thickening/dewatering is a process of removing water to reduce the volume of a sludge stream and decrease the cost of its handling ${ }^{[8,9,15]}$. Thickening/dewatering methods include centrifugation $^{[16]}$, sedimentation ${ }^{[17]}$, vacuum filters ${ }^{[18]}$, belt filter press ${ }^{[19]}$, drying beds ${ }^{[20]}$ and sludge lagoons ${ }^{[21]}$.

Sludge composting results in moisture removal, volume reduction, stabilization of waste and destruction of pathogens. Composting techniques include: windrows ${ }^{[22]}$, biopiles ${ }^{[23]}$ and bioreactors ${ }^{[8]}$. Windrows are elongated, dome shaped piles, under $3 \mathrm{~m}$ in height, normally constructed on a lined surface (with geotextile material) with a liquid collection system $^{[8]}$. The biopiling process begins with mixing the contaminated sludge/soil with straw and fertilizer amendments and the bio-pile is then turned over once a month to accelerate the bio-remediation process ${ }^{[23]}$. Bioreactors are closed composters which are used when controlled conditions such as temperature and humidity are essential $^{[8]}$.

Washing is currently used to treat soil/sludges containing organic and inorganic contaminants. This technology is considered to be a relatively low-cost alternate to land disposal ${ }^{[24]}$. Soil washing is a physical/chemical treatment process which normally involves:

- Excavation and staging of contaminated soil/sludge

- Pretreatment of soil/sludge to remove large objects and oversized clods

- Washing the soil/sludge with water (chemical extracts may be used in the wash water) to separate the contaminants

- Recovering the clean soil/sludge fraction that can be redeposited on site ${ }^{[25]}$

The removal efficiencies are highly dependent on the physical and chemical characteristics of the soil/sludge and contaminants. The process depends on the Cation Exchange Capacity (CEC) of the soil/sludge which is a measure of the soil ability to exchange cations. Cations are held by electrostatic forces on the soil/sludge particle surfaces to balance the negatively charged clays ${ }^{[26]}$. A high CEC in soil indicates a stronger bond between the cations located on the surface of the soil (higher capacity to hold onto cations) and it is less likely that they will exchange with other cations. In comparison to other sludge remediation techniques, sludge washing has many advantages including: less time required, higher treatment efficiency, low requirements of chemicals/biological agents to treat pollutants in sludge and ease of operation $^{[24]}$.

Water demineralization: Methods of the demineralization of water include: distillation, membrane separation and electrodialysis processes. Distillation is based on the fact that the water evaporates, while the salt components stay behind ${ }^{[27]}$.

Membrane separation processes are pressure intensive operations in which solutes of different molecular weights are separated from solution by applying moderate to high differential pressure across membranes ${ }^{[28,29]}$. There are different membrane separation processes based on particle sizes: microfiltration, ultrafiltration, nanofiltration and reverse osmosis. In principle, large molecules are separated from solution through membranes made from synthetic polymers as well as ceramic materials ${ }^{[28]}$. Unlike conventional filtration, in these processes the solution flows parallel to the membrane, cleaning away any particles remaining on the membrane surface. Microfiltration membrane pore-size range between 0.1$10 \mu \mathrm{m}$ and requires up to $2-3 \mathrm{~atm}$ differential pressure. Ultrafiltration operates around 3-10 atm differential pressures and utilizes $0.001-0.1 \mu \mathrm{m}$ pore-size membranes.

In case of nanofiltration, differential pressure above $15-20 \mathrm{~atm}$ is applied to $0.0001-0.001 \mu \mathrm{m}$ poresize membrane to separate low-molecular-weight organic solutions like alcohol from organic solutes, suspended solids and polyvalent ions. Osmosis is a driving force for the flow of solvent molecules due to a difference in chemical potential on the two sides of a membrane ${ }^{[30]}$. Reverse osmosis is the movement of water in a direction opposite to that it would move to in a normal osmosis ${ }^{[28]}$. Unlike microfiltration and ultrafiltration, reverse osmosis operates similar to nanofiltration, albeit at very high pressure (up to over 20-30 atm) and separates salts as well as macromolecules and particles, allowing only the water molecules. In fact, in many European countries almost all newly set up water desalination plants for potable water are based on reverse osmosis process despite having higher installation and operating costs ${ }^{[29]}$.

Electrodialysis is an another option in removing the salts from the saline solution utilizing electrophoresis of ionic substances in solutions and the selective permeability of ionized inorganic and ionized organic exchange membranes. 
Electrodialysis has several advantages over all other techniques of wastewater demineralization including: no evaporation are required, low power requirement for pumping, relatively cheaper, use of naturally occurring catalysts that are easier to regenerate and ease of operation ${ }^{[31]}$.

Zeolites are composed of $\mathrm{SiO}_{4}$ tetrahedra (Fig. 1) in which each oxygen is shared between two tetrahedra, occasionally $\mathrm{Al}^{3+}$ ions in place of $\mathrm{Si}^{4+[32]}$. The chemical composition for various types of zeolites is shown in Table $1^{[34]}$. The ion-exchangeability is due to the presence of extra-frame cations, located in the regular array of channels and cages. Cations are bound to the lattice and to water molecules, which normally fill the zeolite micropores. Substitution is stoichiometric and unless partial or total exclusion occurs, the entire cation exchange capacity can be covered ${ }^{[35]}$.

Zeolites are commonly used in water softening processes to exchange $\mathrm{Ca}^{2+}$ for $\mathrm{Na}^{+[36]}$. Electrodialysis can be performed on saline water (containing $\mathrm{CaCl}_{2}$, $\mathrm{MgCl}_{2}$ and $\mathrm{NaCl}$ ) using an ion-exchange column consisting of zeolite as a medium, in which the $\mathrm{Na}^{+}$, $\mathrm{Ca}^{+}$and $\mathrm{Mg}^{+}$ions can be exchanged for $\mathrm{H}^{+}$ion and the $\mathrm{Cl}^{-}$ion can be exchanged for $\mathrm{OH}^{-}$ion.

\section{EXPERIMENTAL APPARATUS}

Soil washing unit: A simple soil washing unit was constructed as seen in Fig. 2. It consisted of three cylinders, one for the clean water $(10 \mathrm{~cm}$ diameter and $100 \mathrm{~cm}$ height), the second for the contaminated soil $(10 \mathrm{~cm}$ diameter and $25 \mathrm{~cm}$ height) and the third for the collection of wash water $(10 \mathrm{~cm}$ diameter and $25 \mathrm{~cm}$ height). The cylinders were constructed from Plexiglas pipes. The bottom of each cylinder was made of a Plexiglas circular plate which was glued into the bottom end of the pipe and fastened with four screws.

To prevent sediments from traveling through the tubing, a GeoTech ${ }^{\circledR}$ screen (GeoTech Environmental Inc., Tamarac, Florida) was placed at the bottom of the soil cylinder. The cylinders were connected by $1.5 \mathrm{~cm}$ diameter Tygon ${ }^{\circledR}$ tubing. Two $1.5 \mathrm{~cm}$ ball valves (Northeast Equipments Ltd., Halifax, Nova Scotia) were used to facilitate the movement of clean water into the soil cylinder and the movement of saline water into the wash water collection cylinder. A motor with speed controller (Dayton Electric MFG. Co., Chicago, Illinois) was used to mix the water/soil mixture to allow for the transfer of salts from the soil to the water.

Water desalination unit: A simple water desalination unit was constructed as shown in Fig. 3. It consisted of
Table 1: Chemical composition of some natural zeolites ${ }^{[34]}$

\begin{tabular}{lll}
\hline Zeolite & Idealized unit-cell formula & Si /Al ratio \\
\hline Chabazite & $\mathrm{Ca}_{6}\left[\mathrm{Al}_{12} \mathrm{Si}_{24} \mathrm{O}_{72}\right] \cdot 40 \mathrm{H}_{2} \mathrm{O}$ & $1.43-4.18$ \\
Clinoptilolite & $\mathrm{Na}_{3} \mathrm{~K}_{3}\left[\mathrm{Al}_{6} \mathrm{Si}_{30} \mathrm{O}_{72}\right] \cdot 2 \mathrm{H}_{2} \mathrm{O}$ & $2.92-5.04$ \\
Erionite & $\mathrm{Na}_{2} \mathrm{~K}_{2} \mathrm{MgCa}_{1.5}\left[\mathrm{Al}_{9} \mathrm{Si}_{27} \mathrm{O}_{72}\right] \cdot 27 \mathrm{H}_{2} \mathrm{O}$ & $3.05-3.99$ \\
Ferrierite & $\mathrm{Na}_{2} \mathrm{Mg}_{2}\left[\mathrm{Al}_{6} \mathrm{Si}_{30} \mathrm{O}_{72}\right] .18 \mathrm{H}_{2} \mathrm{O}$ & $3.79-6.14$ \\
Heulandite & $\mathrm{Ca}_{4}\left[\mathrm{Al}_{8} \mathrm{Si}_{28} \mathrm{O}_{72}\right] \cdot 24 \mathrm{H}_{2} \mathrm{O}$ & $2.85-4.31$ \\
Laumontite & $\mathrm{Ca}_{4}\left[\mathrm{Al}_{8} \mathrm{Si}_{16} \mathrm{O}_{48}\right] \cdot 16 \mathrm{H}_{2} \mathrm{O}$ & $1.95-2.25$ \\
Mordenite & $\mathrm{Na}_{8}\left[\mathrm{Al}_{8} \mathrm{Si}_{40} \mathrm{O}_{96}\right] \cdot 24 \mathrm{H}_{2} \mathrm{O}$ & $4.19-5.79$ \\
Phillipsite & $\mathrm{Na}_{2} \mathrm{~K}_{2} \mathrm{Ca}_{2}\left[\mathrm{Al}_{6} \mathrm{Si}_{16} \mathrm{O}_{32}\right] \cdot 12 \mathrm{H}_{2} \mathrm{O}$ & $1.45-2.87$ \\
\hline
\end{tabular}

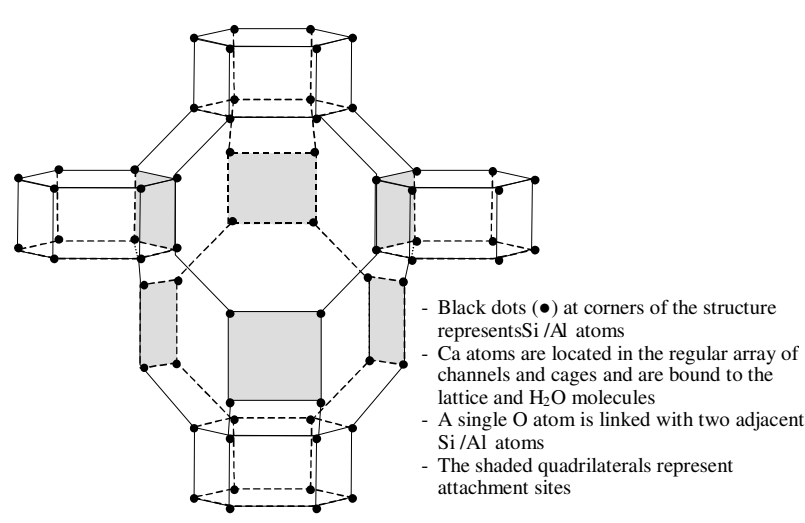

Fig. 1: Three dimensional structure of chabazite, the dominant from in Nova scotian mountain stronach zeolites ${ }^{[33]}$

three cylinders, one for the waste water $(10 \mathrm{~cm}$ diameter and $50 \mathrm{~cm}$ height), the second was used as ion-exchange column ( $5 \mathrm{~cm}$ diameter and $25 \mathrm{~cm}$ height) and the third was used for collection of clean water (10 $\mathrm{cm}$ diameter and $25 \mathrm{~cm}$ height).

The cylinders were constructed from Plexiglas pipes. The bottom of each cylinder was made of a Plexiglas circular plate which was glued into the bottom end of the pipe and fastened with four screws. A GeoTech $^{\circledR}$ screen (GeoTech Environmental Inc., Tamarac, Florida) was placed at the bottom of the ionexchange column before filling it with zeolite. The three cylinders were connected with $1.5 \mathrm{~cm}$ diameter Tygon ${ }^{\circledR}$ tubing. A motor with speed controller (Dayton Electric MFG. Co., Chicago, Illinois) was used to mix the wash water.

\section{MATERIALS AND METHODS}

Sludge: Sludge samples were collected in July from a gas production field in British Columbia, Canada. The sludge characteristics are shown in Table 2. The analyses were performed at Philip Analytical Service, Dartmouth, Nova Scotia. The sodium absorption ratio (SAR) was calculated using the concentration of $\mathrm{Na}, \mathrm{Ca}$ 
Am. J. Environ. Sci., 4 (4): 388-396, 2008

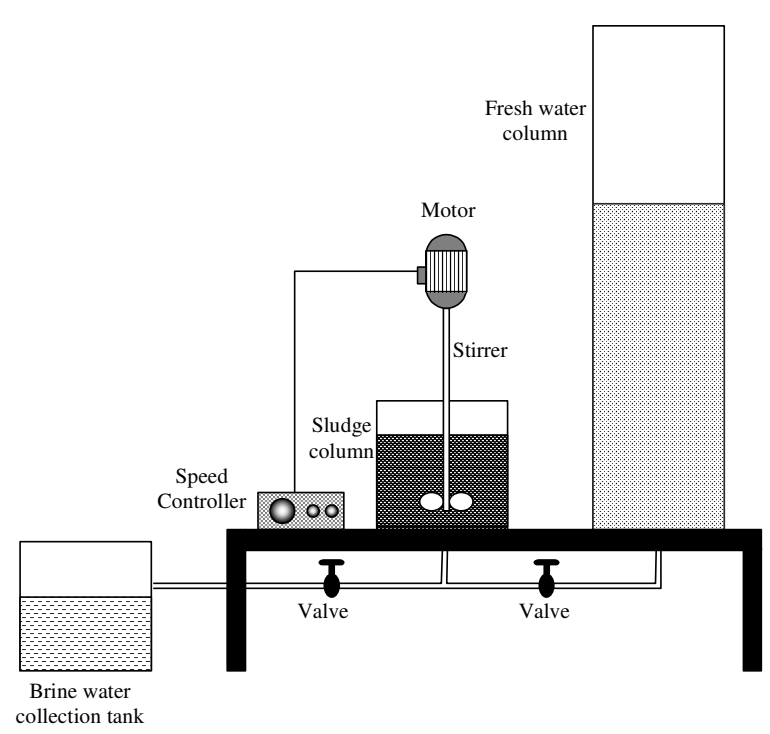

Fig. 2: Sludge demineralization unit

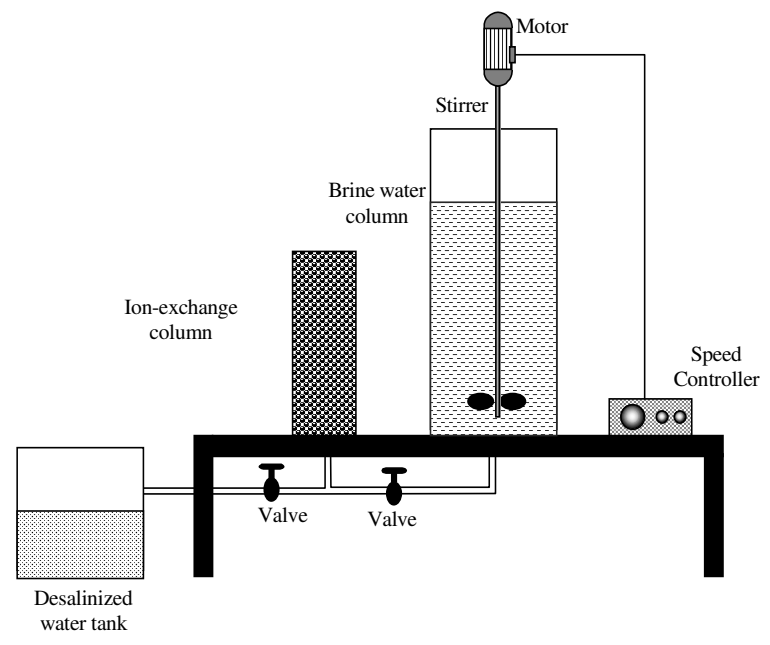

Fig. 3: Water desalination unit

and $\mathrm{Mg}$ ions ( $\mathrm{m} \mathrm{mol} \mathrm{L}^{-1}$ ) according to the following equation ${ }^{[1]}$.

$$
\mathrm{SAR}=\frac{\left[\mathrm{Na}^{+}\right]}{\left[\mathrm{Ca}^{++}\right]+\left[\mathrm{Mg}^{++}\right]}
$$

A $500 \mathrm{~g}$ sample was placed in a convection oven (Fisher Scientific) to dry at $105^{\circ} \mathrm{C}$ for $24 \mathrm{~h}$ according to the procedure described by Black et al. ${ }^{[37]}$. The dried sample was in the form of large clumps $(50 \mathrm{~mm}$ in length). These clumps were reduced in size using a hammer. Then, $100 \mathrm{~g}$ of this dried granule sample were placed in the sieve shaker (W.S. Tyler Incorporated,
Table 2: Sludge characteristics

\begin{tabular}{lcc}
\hline Item & Value & Industrial limit \\
\hline Soluble elements $\left(\mathbf{m g ~ k g}^{-1}\right)$ & & \\
Calcium & 95 & na \\
Magnesium & 78 & na \\
Sodium & 3400 & na \\
Chloride & 5750 & na \\
Total salt $\left(\mathrm{mg} \mathrm{kg}^{-1}\right)$ & 9323 & -- \\
Electrical Conductivity $\left(\mathrm{dS} \mathrm{m}{ }^{-1}\right)$ & 24.2 & 4 \\
Sodium Absorption Ratio & 35.1 & 12 \\
CEC $\left(\mathrm{cmoL} \mathrm{kg}^{-1}\right)$ & 40.3 & -- \\
pH & 6.7 & $6.6-8.5$ \\
\hline na = not applicable & \\
& & \\
Table 3: Size limits of soil seperated & \\
\hline Name of separate & & \\
& & Diameter range \\
Very coarse sand & $2.0-1.0$ \\
Coarse sand & $1.0-0.5$ \\
Medium sand & $0.5-0.25$ \\
Fine sand & $0.25-0.10$ \\
Very fine sand & $0.10-0.05$ \\
Silt sand & $0.05-0.002$ \\
Clay & $<0.002$ \\
\hline
\end{tabular}

Table 4: Sieve analysis results

\begin{tabular}{lllll}
\multicolumn{5}{l}{ Table 4: Sieve analysis results } \\
\hline Mesh & $\begin{array}{l}\text { Screen } \\
\text { opening } \\
(\mathrm{mm})\end{array}$ & $\begin{array}{l}\text { Mass } \\
\text { fraction } \\
\text { retained }\end{array}$ & $\begin{array}{l}\text { Average particle } \\
\text { diameter in } \\
\text { increment } \\
(\mathrm{mm})\end{array}$ & $\begin{array}{l}\text { Cumulative fraction } \\
\text { smaller than } \\
\text { screen opening }\end{array}$ \\
\hline 14 & 1.410 & 0.487 & - & 0.513 \\
18 & 1.000 & 0.091 & 1.21 & 0.422 \\
20 & 0.850 & 0.048 & 0.92 & 0.374 \\
30 & 0.595 & 0.066 & 0.72 & 0.308 \\
40 & 0.425 & 0.057 & 0.51 & 0.251 \\
80 & 0.180 & 0.150 & 0.30 & 0.100 \\
100 & 0.150 & 0.015 & 0.17 & 0.085 \\
Pan & - & 0.085 & 0.08 & 0.000 \\
\hline
\end{tabular}

Gastonia, North Carolina) for $30 \mathrm{~min}$.

The diameter ranges for various soil particles as reported by Black et al. ${ }^{[37]}$ are presented in Table 3 . Based on particle size distribution (Table 4), the soil/sludge composition can be determined in terms of percentage of sands, silt and clay. The results indicate that most of the sludge is made up of very fine sand and clay.

The value of $48.7 \%$ of very coarse sand particles was not considered representative of the sample because the large clumps were formed during drying and could be broken to smaller particles with a relatively small finger pressure. When the sludge was mixed with water, the clumps did dissolve and it was, therefore, assumed that the sludge had a very high clay content.

Zeolite: The zeolites (Fig. 4) used as the ion-exchange medium is a Nova Scotian variety called Mountain 
Am. J. Environ. Sci., 4 (4): 388-396, 2008

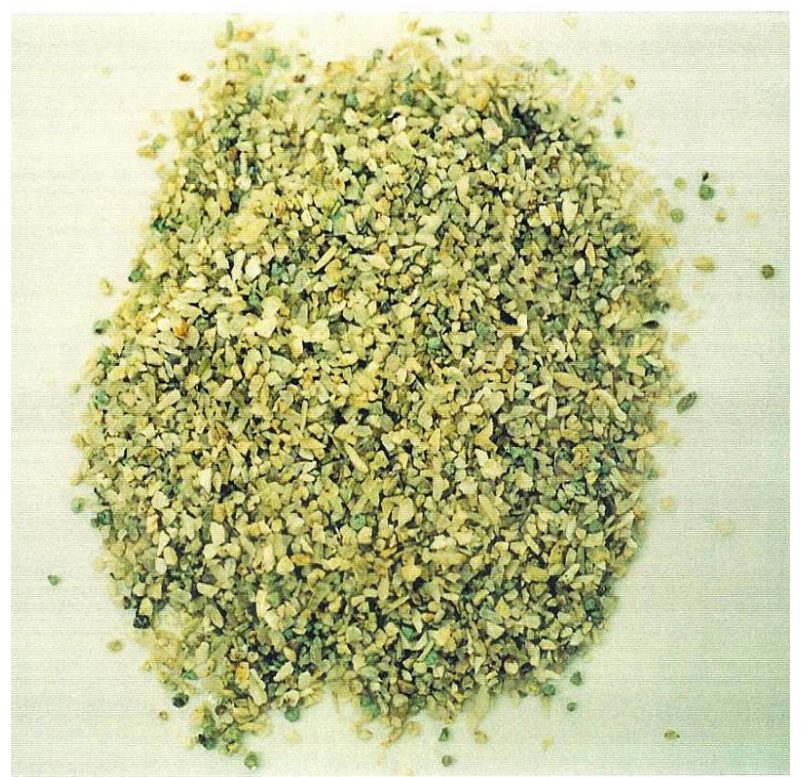

Fig. 4: Mountain stronach zeolite

Stronach. It was collected from Stronach Pit in Nova Scotia and had a Carbon Exchange Capacity (CEC) of $144 \mathrm{cmoL} \mathrm{kg}^{-1}$.

\section{EXPERIMNTAL PROCEDURE}

Salt solubility: The solubility of salts was determined at different temperature as shown in Table 5. The amount of water required $\left(\mathrm{mL} \mathrm{kg}^{-1}\right.$ soil) for each salt type is shown in Table 6.

Sludge demineralization: A $500 \mathrm{~g}$ sample of sludge was placed in the sludge column and mixed for approximately 30 seconds. One L distilled deionized water ( $\mathrm{EC}=0$ at room temperature) was then added by percolating up through the bottom of the sludge column. The sludge/water mixture was mixed at a constant speed $(50 \mathrm{rpm})$ for $10 \mathrm{~min}$. The water was then drained. Several washes were performed. After each wash, the wash water was centrifuged (International Equipments Company, Needham Heights, Massachusetts) for $40 \mathrm{~min}$ and then filtered under vacuum using Whatman Filter Paper (No. 40, Fisher Scientific, Montreal, Quebec). The solids were returned to the sludge column for the next wash. This process was continued until no salts were transferred from the sludge to the wash water (as indicated by constant electrical conductivity values). The samples obtained for the sludge and wash water were analyzed for salt concentration and the salt removal efficiency was calculated.
Table 5: Salt solubility

\begin{tabular}{lllll}
\hline \multicolumn{5}{c}{$\begin{array}{c}\text { Solubility } \\
\left(\mathrm{g} \mathrm{L}^{-1}\right)\end{array}$} \\
& - & $10^{\circ} \mathrm{C}$ & $20^{\circ} \mathrm{C}$ & $100^{\circ} \mathrm{C}$ \\
\hline Salt & $0^{\circ} \mathrm{C}$ & 650 & 745 & 1590 \\
$\mathrm{CaCl}_{2}$ & 595 & 535 & 545 & 727 \\
$\mathrm{MgCl}_{2}$ & 528 & 358 & 360 & 391 \\
$\mathrm{NaCl}$ & 357 & & & \\
\hline
\end{tabular}

Table 6: Water requirement for the sludge (at room temperature)

\begin{tabular}{llll}
\hline Parameter & $\mathrm{NaCl}$ & $\mathrm{CaCl}_{2}$ & $\mathrm{MgCl}_{2}$ \\
\hline $\begin{array}{l}\text { Amount of salt available } \\
\left(\mathrm{mg} \mathrm{kg}^{-1} \text { soil) }\right.\end{array}$ & 8642.71 & 263.05 & 305.49 \\
$\begin{array}{l}\text { Solubility }\left(\mathrm{mg} \mathrm{mL}^{-1}\right) \\
\begin{array}{l}\text { Water requirement } \\
\left(\mathrm{mL} \mathrm{kg}^{-1} \text { soil) }\right.\end{array}\end{array}$ & 360 & 545 & 745 \\
\hline
\end{tabular}

$$
\begin{array}{lll}
\mathrm{Na}^{+}+\mathrm{Cl}^{-} & \rightarrow & \mathrm{NaCl} \\
\mathrm{Ca}^{++}+2 \mathrm{Cl}^{-} & \rightarrow & \mathrm{CaCl}_{2} \\
\mathrm{Mg}^{++}+2 \mathrm{Cl}^{-} & \rightarrow & \mathrm{MgCl}_{2}
\end{array}
$$

Where:

$$
\begin{aligned}
& \mathrm{Na}=22.99 \mathrm{~g} \mathrm{moL}^{-1} \\
& \mathrm{Cl}=35.45 \mathrm{~g} \mathrm{moL}^{-1} \\
& \mathrm{Ca}=40.08 \mathrm{~g} \mathrm{moL}^{-1} \\
& \mathrm{Mg}=24.31 \mathrm{~g} \mathrm{moL}^{-1}
\end{aligned}
$$

Water desalination: To test the salt removal from the wash water, the zeolite was placed in the column and the wash water was filtered up through zeolite column until the water filled the entire column. The water was kept in the column for $20 \mathrm{~min}$ and was then drained. The salt concentration in the treated water was determined and the desalination efficiency was calculated.

\section{RESULTS AND DISCUSSION}

Sludge characteristics: The total amounts of measured and calculated salts are summarized in Table 7. The $\mathrm{CaCl}_{2}: \mathrm{MgCl}_{2}: \mathrm{NaCl}$ ratio was 1:1.16:36.61. The calculated total salt concentration was less than that obtained from the laboratory analysis by $1.2 \%$ which is acceptable analytical error. The electrical conductivity (EC) is a measure of the solution ability to conduct electricity which is related to the concentration of ions and their electrical charges.

The EC value was $42.2 \mathrm{dS} \mathrm{m}^{-1}$ indicating a very saline sludge. The SAR value was 35.1 which is higher than industrial limit of 12 indicating high level of 
sodicity. The Cation Exchange Capacity (CEC) is an important factor in determining the suitability of washing process for the removal of salts. The CEC for the saline sludge was $40 \mathrm{cmoL} \mathrm{kg}^{-1}$ which is considered to be high indicating that the soil texture is clay to clay $\operatorname{loam}^{[26]}$.

Sludge washing: Initially, three washes were performed on each sludge sample. Two liters of water were used in each wash for each $\mathrm{kg}$ of sludge. The results showed that the majority of the salt was removed in the first wash and no salt was removed in the third wash. The sludge water mixture took $36 \mathrm{~h}$ to completely settle.

The salt removed in each wash and the total removal efficiency results are presented in Table 8 . The average salt removal efficiency was $94.47 \%$. The treated sludge contained $515 \mathrm{mg}$ salt $\mathrm{kg}^{-1}$ sludge (or $0.05 \% \mathrm{w} \mathrm{w}^{-1}$ ) and can be applied on agricultural land $^{[38]}$.

Soil/sludge washing was implemented recently for removal of heavy metals $(\mathrm{Cd}, \mathrm{Co}, \mathrm{Cr}, \mathrm{Cu}, \mathrm{Mn}, \mathrm{Ni}, \mathrm{Pb}$ and $\mathrm{Zn}$ ). Chemicals have also been added to the water to facilitate the washing process. These include: ethylenediaminetetraacetic acid (EDTA) ${ }^{[39]}$, ferric chloride $^{[40]}$ and high-concentration chloride solutions $\left(\mathrm{CaCl}_{2} \text { and } \mathrm{NaCl}\right)^{[41]}$.

Andrade et $a l .{ }^{[39]}$ investigated the effect of water to soil ratio (between 1:5-2:5) on the chelating efficiency of heavy metals $(\mathrm{Cr}, \mathrm{Cu}, \mathrm{Ni}, \mathrm{Pb}$ and $\mathrm{Zn}$ ) during washing process which required $24 \mathrm{~h}$ of settling time after $16 \mathrm{~h}$ of constant agitation at $125 \mathrm{rpm}$. Their results showed removal efficiency of $95.0-99.9 \%$. Makino et al. ${ }^{[40]}$ have reported two washes with a soil to water ratio of $2: 3$ and a settling time of around $24 \mathrm{~h}$ after each wash to attain optimal removal of Cd (up to 66\%) from soil.

No study has been reported on sludge washing for desalination purpose. In this study, the quantity of fresh water required as well as overall process time (sludgefresh water mixing and settling time) are within the range reported in the literature for soil washing. Thus, the results obtained from the present study would provide the basis for the development of a large scale sludge desalination process.

Desalination of wash water: The zeolite (Chabazite) in the ion-exchange column was tested using upflow percolation. The Chabazite $\left(\mathrm{Ca}_{6}\left[\mathrm{Al}_{12} \mathrm{Si}_{24} \mathrm{O}_{72}\right] \cdot 40 \mathrm{H}_{2} \mathrm{O}\right)$ can only remove the $\mathrm{Na}$ ions. The results are shown in Table 9. A sodium removal efficiency of $75.25 \%$ was achieved.

\begin{tabular}{lc} 
Table 7: Mass balance on soluble salts \\
\hline Salt & $\begin{array}{c}\text { Concentration } \\
\left(\mathrm{mg} \mathrm{kg}^{-1}\right)\end{array}$ \\
\hline $\mathrm{NaCl}$ & 8642.71 \\
$\mathrm{Na}$ & 3400.00 \\
$\mathrm{Cl}$ & 5242.71 \\
$\mathrm{CaCl}$ & \\
$\mathrm{Ca}$ & 263.05 \\
$\mathrm{Cl}$ & 95.00 \\
$\mathrm{MgCl}_{2}$ & 168.05 \\
$\mathrm{Mg}$ & 305.49 \\
$\mathrm{Cl}$ & 78.00 \\
Total calculated & 227.49 \\
Total lab analysis & 9211.25 \\
Error $(\%)$ & 9323.00 \\
\end{tabular}

Table 8: Salt removal from the sludge

\begin{tabular}{|c|c|c|c|c|c|}
\hline \multirow[b]{2}{*}{ Sample } & \multirow{2}{*}{$\begin{array}{l}\text { Original salt } \\
\quad(\mathrm{mg})\end{array}$} & \multicolumn{3}{|c|}{$\begin{array}{l}\text { Salt removal } \\
(\mathrm{mg})\end{array}$} & \multirow{2}{*}{$\begin{array}{c}\text { Removal efficiency } \\
(\%)\end{array}$} \\
\hline & & Wash 1 & Wash 2 & Total & \\
\hline 1 & 4661.50 & 2723.19 & 1680.40 & 4403.59 & 94.47 \\
\hline 2 & 4661.50 & 2739.80 & 1660.92 & 4400.72 & 94.41 \\
\hline 3 & 4661.50 & 2746.64 & 1660.50 & 4407.14 & 94.53 \\
\hline 4 & 4661.50 & 2733.40 & 1670.60 & 4404.09 & 94.48 \\
\hline Average & 4661.50 & 2735.78 & 1668.11 & 4403.89 & 94.47 \\
\hline
\end{tabular}

Original soil sample $=500 \mathrm{~g}$, Total salt concentration $=9323 \mathrm{~g} / \mathrm{kg}$ soil

Table 9: Sodium removal from the wash water

\begin{tabular}{lcccc}
\hline Sample & $\begin{array}{c}\text { Original salt } \\
(\mathrm{mg})\end{array}$ & $\begin{array}{c}\text { Final salt } \\
(\mathrm{mg})\end{array}$ & $\begin{array}{c}\text { Salt reduction } \\
(\mathrm{mg})\end{array}$ & $\begin{array}{c}\text { Removal efficiency } \\
(\%)\end{array}$ \\
\hline 1 & 400 & 98 & 302 & 75.50 \\
2 & 400 & 100 & 300 & 75.00 \\
3 & 400 & 97 & 301 & 75.25 \\
4 & 400 & 99 & 301 & 75.25 \\
Average & 400 & 99 & 301 & 75.25 \\
\hline
\end{tabular}

Average salt concentration $=2200 \mathrm{mg} / \mathrm{L}$, Average sodium concentration $=800 \mathrm{mg} / \mathrm{L}$, A removal efficiency of $99.79 \%$ was obtained with a two column ion-exchange system. 
These results suggest that a series of ion-exchange column (with Chabazite) will most likely be required to attain a higher removal efficiency of $\mathrm{Na}$ ions. When a two column ion-exchange system (with Chabazite) was used the Na removal efficiency increased from 75.25$99.79 \%$.

Use of zeolites for water desalination/purification have been reported by many researchers ${ }^{[42-44]}$. Caputo et $a l .^{[42]}$ reported reductions in contaminants of up to 99.99\% using a series of zeolite columns depending upon type of zeolite, valance of salt cation and salt concentration. Zhao et al. ${ }^{[44]}$ reported $89.8 \%$ reduction of ammonium in municipal wastewater after repeated regeneration cycle in zeolites.

Utilization of zeolite columns in series for desalination of wash water obtained from the sludge washing process could be a plausible alternative to the cost intensive reverse osmosis and other membrane based processes. The sludge investigated in the present study was enriched in $\mathrm{Na}$ ions. Therefore, use of $\mathrm{Na}$ free zeolite (Chabazite) was the logical approach for the removal of $\mathrm{Na}$ ions which resulted in a removal efficiency of sodium salt of $99.79 \%$ using two column ion-exchange system. However, the wastewater had a total salt concentration of $2200 \mathrm{mg} \mathrm{L}^{-1}$ of which 2039 $\mathrm{mg} \mathrm{L}^{-1}$ is the sodium chloride (the remaining $161 \mathrm{mg}$ $\mathrm{L}^{-1}$ were in the forms of calcium and magnesium chlorides). Therefore, the overall salt removal efficiency will only be $92.9 \%$. The treated water will contain 144.27 $\mathrm{MgCl}_{2}, 142.22 \mathrm{CaCl}_{2}$ and $126.52 \mathrm{mg} \mathrm{L}^{-1}$ $\mathrm{NaCl}$ giving a total salt concentration of $314.0 \mathrm{mg} \mathrm{L}^{-1}$. The salt concentration in the treated wash water is below the established Canadian limits ${ }^{[7]}$.

\section{CONCLUSIONS}

The particle size distribution of sludge sample indicated the presence of very fine sand and clay. The electrical conductivity of the sludge was $42.2 \mathrm{dS} \mathrm{m}^{-1}$ indicating very saline sludge and the Cation Exchange Capacity (CEC) was $40 \mathrm{cmoL} \mathrm{kg}^{-1}$ which was very suitable for ion-exchange process. The desalination of the saline sludge by washing and removal of salt using zeolite based ion-exchange column was very effective.

Two washings of sludge using demineralized water achieved $94.47 \%$ salt removal efficiency and resulted in final salt concentration of $515 \mathrm{mg}$ salt $\mathrm{kg}^{-1}$ sludge (or $\left.0.05 \% \mathrm{w} \mathrm{w}^{-1}\right)$. The treated sludge can be applied on agricultural land as per the Canadian Guidelines. The ion-exchange treatment of the wash water was also very effective. A single column with zeolite (Chabazite) achieved $72.25 \% \mathrm{Na}$ removal efficiency while the two column ion-exchange system achieved $\mathrm{Na}$ removal efficiency of $92.96 \%$.

The $\mathrm{Ca}$ and $\mathrm{Mg}$ ions were under regulatory limits and required no further treatment. The final salt concentration in the wash water was $314.0 \mathrm{mg} \mathrm{L}^{-1}$ which is below the limits established by the Canadian Guidelines. For complete removal of total salts, a series of ion-exchange columns with multiple zeolites (for removal of $\mathrm{NaCl}, \mathrm{MgCl}_{2}$ and $\mathrm{CaCl}_{2}$ ) will be required.

\section{ACKNOWLEDGEMENTS}

The research was funded by National Science and Engineering Council of Canada (NSERC). The financial support of Killam Trusts of Dalhousie University in the form of post doctoral fellowship to Dr M. Verma is highly appreciated.

\section{REFERENCES}

1. Dudas, M.J., 1996. Reclamation of Soils With Salt Spills. Technical Report, Calgary Environmental Tradeshow and Conference, Calgary, Alberta.

2. Rebhun, M., 2004. Desalination of reclaimed wastewater to prevent salinization of soils and groundwater. Desalination, 160 (2): 143-149.

3. Einav, R., K. Harussi and D. Perry, 2003. The footprint of the desalination processes on the environment. Desalination, 152 (1-3): 141-154.

4. Burley, M.J., 1988. Reclamation of brine spill sites. Spill Technology Newsletter, Environment Canada, Ottawa, Ontario, 13 (1): 3-16.

5. Gacia, E., O. Invers, M. Manzanera, E. Ballesteros and J. Romero, 2007. Impact of the brine from a desalination plant on a shallow seagrass (Posidonia oceanica) meadow. Estuarine, Coastal and Shelf Sci., 72 (4): 579-590.

6. Mohamed, A.M.O., M. Maraqa and J. Al Handhaly, 2005. Impact of land disposal of reject brine from desalination plants on soil and groundwater. Desalination, 182 (1-3): 411-433.

7. CCME, 2006. Canadian Environmental Quality Guidelines. Canadian Council of the Ministers of the Environment, Winnipeg, MB.

8. Rhymer, C.E., L.J. Schwartz, R.B. Wengerand and M.G. Kohrell, 1995. Waste Management and Resource Recovery. CRC Press Inc., Boca Raton, Florida.

9. Ormeci, B., 2007. Optimization of a full-scale dewatering operation based on the rheological characteristics of wastewater sludge. Water Res., 41 (6): 1243-125. 
10. Ghaly, A.E., A. Snow and B.E. Faber, 2007. Effective coagulation technology for treatment of grease filter wastewater. Am. J. Environ. Sci., 3 (1): 19-29.

11. Hartong, B.H., M. Abu-Daabes, T. Le, M. Saidan and S. Banerjee, 2007. Sludge dewatering with cyclodextrins. Water Res., 41 (6): 1201-1206.

12. Deneux-Mustin, S., B.S. Lartiges, G. Villemin, F. Thomas, J. Yvon, J.L. Bersillon and D. Snidaro, 2001. Ferric Chloride and Lime conditioning of activated sludges: An electron microscopic study on resin-embedded samples. Water Res., 35 (12): 3018-3024.

13. Chu, C.P., D.J. Lee and C.Y. Chang, 2001. Thermal pyrolysis characteristics of polymer flocculated waste activated sludge. Water Res., 35 (1): 49-56.

14. Wojciechowska, E., 2005. Application of microwaves for sewage sludge conditioning. Water Res., 39 (19): 4749-4754.

15. Krzemieniewski, M., M. Dębowski, W. Janczukowicz and J. Pesta, 2003. Effect of Sludge Conditioning by Chemical Methods with Magnetic Field Application. Polish J. Environ. Stud., 12 (5): 595-605.

16. Chu, C.P., D.J. Lee and C.Y. Chang, 2005. Energy demand in sludge dewatering. Water Res., 39 (9): 1858-1868.

17. Lee, S.J., C.P. Chu, R.B.H. Tan, C.H. Wang and D.J. Lee, 2003. Consolidation dewatering and centrifugal sedimentation of flocculated activated sludge. Chemical Eng. Sci., 58 (9): 1687-1701.

18. Besra, L., B.P. Singh, P.S.R. Reddy and D.K. Sengupta, 1998. Influence of surfactants on filter cake parameters during vacuum filtration of flocculated iron ore sludge. Powder Technol., 96 (3): 240-247.

19. Day, P. and P. Giles, 2002. Innovative belt filter press takes the hard work out of sludge dewatering. Filtration and Separation, 39 (8):18-20.

20. Yamaoka, M. and K. Hata, 2003. Improvements in drying beds for non-concentrated sludge. Adv. Environ. Res., 7 (3): 721-725.

21. van der Steen, P., A. Brenner, J. van Buuren and G. Oron, 1999. Post-treatment of UASB reactor effluent in an integrated duckweed and stabilization pond system. Water Res., 33 (3): 615620 .

22. Tai, H.S. and W.H., He, 2007. A novel composting process for plant wastes in Taiwan military barracks. Resour., Conserv. and Recycling, 51(2): 408-417.
23. Li, L., C.J. Cunningham, V. Pas, J.C. Philp, D.A. Barry and P. Anderson, 2004. Field trial of a new aeration system for enhancing biodegradation in a biopile. Waste Manage., 24 (2): 127-137.

24. Van Benschoten, J.E., M.R. Matsumoto and W.H. Young, 1997. Evaluation and analysis of soil washing for seven lead-contaminated soils. J. Environ. Eng., 123 (3): 217-224.

25. Anderson, W.C., 1993. Innovative Site Remediation Technology: Soil Washing/Soil Flushing. WASTECH, Annapolis, Md.

26. Rowell, D.L., 1994. Soil Science-Methods and Applications. Longman Group, UK.

27. Spiegler, K.S., 1977. Salt-Water Purification. Plenum Press, New York.

28. Brock, T.D., 1983. Membrane filtration: A user's guide and reference manual. Sci. Tec., Inc., Madison, Wisconsin.

29. Fritzmann, C., J. Lowenberg, T. Wintgens and T. Melin, 2007. State-of-the-art of reverse osmosis desalination. Desalination, 216 (1-3): 1-76.

30. Cath, T.Y., A.E. Childress and M. Elimelech, 2006. Forward osmosis: Principles, applications and recent developments. J. Membr. Sci., 281 (12): 70-87.

31. Koide, S. and N. Satta, 2004. Separation Performance of Ion-exchange Membranes for Electrolytes in Drainage Nutrient Solutions subjected to Electrodialysis. Biosyst. Eng., 87 (1): 89-97.

32. Kotz, J.C. and K.F. Purcell, 1991. Chemistry and Chemical Reactivity. Saunders College Publishing: Ft. Worth, Texas.

33. Nakatsuka, A., H. Okada, K. Fujiwara, N. Nakayama and T. Mizota, 2007. Crystallographic configurations of water molecules and exchangeable cations in a hydrated natural CHAzeolite (chabazite). Microporous and Mesoporous Mater., 102 (1-3): 188-195.

34. Baerlocher, C.H., W.M. Meier and D.H. Olson, 2001. Atlas of Zeolite Framework Types. Elsevier Publishing, St. Louis, Missouri.

35. Colella, C., 1996. Ion exchange equilibria in zeolite minerals. Mineralium Deposita, 31 (6): 554-563.

36. Petrucci, R.H. and W.S. Harwood, 1993. General Chemistry-Principles and Modern Applications. Maxwell Macmillan Canada, Toronto, Ontario.

37. Black, C.A., 1965. Methods of Sampling-Part I. American Society of Agronomy and American Society for Testing and Sampling. Madison, Wisconsin. 
38. NSEL, 2004. Guideline under the Environment Act. Environmental Monitoring and Compliance, Nova Scotia Environment and Labour, Halifax, Nova Scotia.

39. Andrade, M.D., S.O. Prasher and W.H. Hendershot, 2007. Optimizing the molarity of a EDTA washing solution for saturated-soil remediation of trace metal contaminated soils. Environ. Pollut., 147 (3): 781-790.

40. Makino, T., H. Takano, T. Kamiya, T. Itou, N. Sekiya, M. Inahara and Y. Sakurai, 2007. Restoration of cadmium-contaminated paddy soils by washing with ferric chloride: $\mathrm{Cd}$ extraction mechanism and bench-scale verification. Chemosphere, DOI: 10.1016/J. Chemosphere. 2007.07.080.

41. Dermont, G., M. Bergeron, G. Mercier and M. Richer-Lafleche, 2007. Soil washing for metal removal: A review of physical/chemical technologies and field applications. J. Hazardous Mater., DOI: 10-1016/J. Jhazmat. 2007.10.043.
42. Caputo, D. and F. Pepe, 2007. Experiments and data processing of ion exchange equilibria involving Italian natural zeolites: a review. Microporous and Mesoporous Mater., 105 (3): 222-231.

43. Caputo, D., B. de Gennaro, P. Aprea, C. Ferone, M. Pansini and C. Colella, 2005. Studies in Surface Science and Catalysis. In: Gamba, A., C. Colella and S. Cosuccia (Edn.), Oxide Based Materials. New Sources, Novel Phases, New Applications, 155: 129-140.

44. Zhao Y.P., T.Y. Gao, S.Y. Jiang and D.W. Cao, 2004. Ammonium removal by modified zeolite from municipal wastewater. J. Environ. Sci., 16 (6): 1001-1004. 